they are formed within incipient vacuoles, or at least within restricting membranes, in agreement with Chaze's ${ }^{8}$ Nicotiana results obtained by different methods. Accumulation in the large vacuoles of storage tissues is a later development.

W. O. James

Oxford Medicinal Plants Scheme, Oxford.

1. Errera, L., Rec. l'Inst. Bot. Bruxelles, 2, 189 (1906).

'James, W. O., and Roberts, M., Quart. J. Pharm. and Pharmacol.,

- Chaze, J., Ann. Sci. Nat. Bot., 14, 5 (1932).

\section{Lethal Effects of D.D.T. on Young Fish}

DEATHS of young fish have been noted in waters which have been sprayed with D.D.T. as an anti-mosquito measure ${ }^{1}$. The following observations on the so-called Kafue 'bream' (Tilapia kafuensis), a common and hardy fish of Rhodesia, are of interest in growing importance of this and other flsh in the diet of Centra] African inhabitants and the official encouragement in fish farming of this species.

In the first experiments, young fish about $1 \mathrm{in.} \mathrm{long} \mathrm{were} \mathrm{put} \mathrm{in}$ clear water in pint jars, one to each jar, and a D.D.T. in paraffin solution $(5 \cdot 2$ per cent para para) was applied in various concentrations. In mosquito work it is usual to specify the D.D.T. concentration at so much per unit surface area, as the larvæ are essentially surfacelivers, but with fish, concentration per volume of water is also important as D.D.T. is very slightly soluble in water, and fish, continuously filtering water in their respiratory actions, are in a favourable position to absorb the poison. Using a concentration equivalent to 1 oz. pure D.D.T. per acre, a normal effective larvicidal concentration (about 1 part of D.D.T. to 18 million of water in this case) all the fish died 1 part of D.D.T. to 18 million of water in this case) all the fish died
within twenty-four hours. With $0.5 \mathrm{oz}$. per acre (1:36 million) 80 per within twenty-four hours. With $0.5 \mathrm{oz}$. per acre $(1: 36$ million) 80 per
cent died in one day and the rest within the next two days; with cent died in one day and the rest within the next
$0.25 \mathrm{oz}$. per acre all were dead within $4-5$ days.

In control experiments using pure paraffin in equal quantities and also using untreated water, fish lived ten or more days before dying, presumably of starvation. A few similar experiments suggested that gammexane powder was also toxic. Further experiments were conducted using twenty-gallon aquaria with clear water, mud bottoms but very slight weed growth, which formed a more normal environment for the fish. At a dose of $1 \mathrm{oz}$. per acre (here only 1 in 48 million because of the deeper vessel) nearly all the fish died within one day; at this concentration and a higher one of 3 oz. per acre some dragonfly larvæ survived although the fish died. There was no mortality at $0 \cdot 33$ oz. per acre $(1: 150$ million).

Experiments were then carried out in fish pools of about $40 \mathrm{sq}$. yd. area and $2 \mathrm{ft}$. deep. The water in these pools was largely kept up by sub-soil seepage and they were weedy, had very muddy bottoms and a sub-soil seepage and they were weedy, had very muddy bottoms and a the D.D.T. was a proximately 70 per cent mortality within four days and then no further deaths. The comparatively heavy dose necessary in this no further deaths. The comparatively heavy dose necessary in this case suggests some absorption or decomposition of the D.D.T. On
vegetation or mud. Even here, however, the lethal dose is within the range used in anti-mosquito measures ${ }^{2}$. Moreover, the shallow waters in which these young fish oceur are just those places likely to be given most attention in the control of mosquitoes. It is clear that D.D.T. applications should be made only with great caution in waters which are breeding-grounds of flsh, of this species at least, where they are an important item of diet.

\section{Department of Game and Tsetse Control, \\ Northern Rhodesia.}

D. P. PIELoU

Aug. 12.

1 Buxton, P. A., Bull. Ent. Res., 36, $165(1945)$.
2 Ribbands, C. R., Bull. Ent. Res., 36 (1945).

\section{Food and Digestive Organs of Lamellibranchs}

Is his comment on my note in Nature ${ }^{1}$, Prof. Yonge ${ }^{2}$ raised the following points: (1) that histological evidence for the secreting function of the digestive diverticula is lacking: $(2)$ that the passage of the chlorophyil colouring matter from the blood into the lumen of the gut through the cells of the digestive diverticula is merely the passage of the indigestible residue after intracellular digestion; (3) that extracellular protease and the style cannot co-exist; (4) that extracellular protease in lamellibranchs is derived from cytolized or burst
phagocytes: (5) that the presence of any significant quantity of animal matter in the gut of lamellibranchs is rare.

The histological evidence is far from lacking ${ }^{3,4}$. Bouin-, Flemming(without acetic) and Bouin-Dubosca-fixed material showed different stages in the formation of the seoretion globules. In such preparations it is easy to note the dropping off of cell-fragments loaded with globules in is easy to note the dropping off of cell-fragments joaded with globules into the lumen of the tubules. From the beginning it was evident to
me that the cells of these organs are of the holocrine type and that the me that the cells of these organs are of the holocrine type and that the replacement of the ripe fragmenting ones is continuously taking place
from nests of replacement cells. It is noteworthy that such globule from nests of replacement cells. It is noteworthy that such globule
formation and fragmentation of diverticula cells has been previously recorded by Prof. Yonge ${ }^{5}$ (loc. cit., p. 41). Nevertheless I have been after a positive experimental proof.

In his explanation of the passage of the chlorophyll colouring matter from the blood into the lumen of the gut through the cells of the digestive diverticula Prof. Yonge raised a very problematic point, namely, the fate of chlorophyll. However, one can only ask what evidence have we that 'intracellular digestion' does really take place in this case and whether it is possible that a substance like chlorophyll in solution after undergoing 'intracellular digestion' would have an indigestible residue of a colour and freshness similar to those of the unaffected material ${ }^{4}$.
The question of the crystalline style has often been raised. In his reasoning, however, Prof. Yonge does not deny the presence of extracellular protease. He only endeavours to derive it from a phagocytic source. This admission affects his argument very seriously. In this connexion I would like to mention that what seems to be of fundamental importance for the existence of the style is the degree of protection afforded to it by the surrounding tissues. In the case of Unio, where the style lies simply in a groove, a few hours of starvation in where the style lies simply in a groove, a few hours of starvation in In Tridacna, on the other hand, where the style lies in a definite cæcum In Tridacna, on the other hand, where the style lies in a deflnite cæcum
with only the head protruding into the stomach, eight days of starvawith only the head protruding into the stomach, eight days of starvation in filtered sea-water scarcely gave any comparative difference in Edmondson ${ }^{7}$ and Yonge ${ }^{8}$ )

The suggested explanation for the presence of 'semi-digested animal remains' in the gut of some lamellibranchs brings us to the very important point of the differentiation between phagocytes, which admittedly can occur in the lumen of the gut, and fragments of the ripe holocrine cells. This has been discussed at some length in a pretion that what Prof. Yonge in his study of Tridacna took to be 17 zooxanthellæ $(7 \mu$ each) ingested in one a moebocyte of $10 \mu$ only (loc. cit., Text-fig. 5, p. 296) is in reality nothing but a mass of secretion globules adhering together. It has been pointed out also that similar clumps of globules or fragments of ripe holocrine cells are of regular occurrence in all the other forms examined (Pinctada sp., Mytilus spp., Ostrea spp.). These fragments sometimes look like phagocytes spp., Ostrea spp.). These fragments sometimes look like phagocytes and are often seen collecting round the food material in the stomach. $O$ strea fed with an emulsion of olive oil. Only what he takes to be phagocytes, I consider nothing but fragments of ripe divertieula cells in virtue of their origin referred to above and the rather quick dispersal of the individual globules they contain. The reference to these structures in the lamellibranchs, as coming f

with the facts (see also Potts ${ }^{10}, \mathrm{p}$. 7). unfortunately Prof. Yonge did not refer to the time at which the search of the gut contents was made. That the search should be made soon after feeding was adequately stressed ${ }^{1}$; and it is no wonder that Fox et al. ${ }^{11}$ and Yonge ${ }^{12}$ have missed such a nimal matter. The first authors have been examining Mytilus 5-8 hours after active feeding had stopped (loc. cit. Footnote, p. 20) and Yonge has been examining the gut contents of Cardium and Mya two days and six hours respectively after being fed with dog-fish blood corpuscles (loc, cit.,
p. 711). On the other hand, Nelson ${ }^{13}$ has been searching some of his p. 711). On the other hand, Nelson ${ }^{13}$ has been searching some of his It is worthy to add that Edge ${ }^{14}$, in his work on the rates of digestion of marine invertebrates, gave the time required for food to pass through californianus also 3 hours and Cardium quadraginariun as 11 hours (see also Dodgson ${ }^{15}$ )

In conclusion, I thank Prof. Yonge for his compliment ${ }^{2}$ and wish to register that without the biochemical investigation carried out by logical studies would have been very difficult to substantiate.

\section{Department of Zoology \\ Fouad I University, \\ Cairo.}

${ }^{1}$ Mansour, K., Nature, 157, 482 (1946).

s Mansour, K., Proc. Egyptian Acad. Sci., 1, No. 1 (1945) (in the press) ${ }^{4}$ Mansour, K., and Zaki, F. George, Proc. Egyptian Acad. Sci., 1, No. 2 (1946) (in the press).

Yonge, C. M., Brit. J. Exp. Biol., 1 (1923).

- Nelson, T. C., J. Morph., 31 (1918)

$?$ Edmondson, C. H., J. Exp. Zool., 30 (1920).

Y Yonge, C. M., Nature, 11\%, 691 (1926).

Yonge, C. M., Great Barrier Reef Expedition Sci. Rep. 1, No. 11, (1936).

${ }^{10}$ Potts, F. A., Biol. Rev., 1, 1 (1923).

12 Fox, D. L., et al., Bull. Scripps Inst. Oceanogr. Univ. Calif. Tech. ge, C. M., Trans

soy., Edin., 54 (1926).

is Edge, E. R., Amer. Midland Naturalist, 15 (1934).

5 Dodgson, R. W., Min. Agri. and Fisheries, Fishery Investigations, Ser. 2. 10, No. 1 (London, 1928).

${ }^{18}$ Mansour-Bek, J. J., Proc. Egyptian Acad. Sci., 1, No. 1 (1945) (in the press).

\section{Extracellular Proteolytic and Lipolytic Enzymes of Some Lamellibranchs}

Prof. YoNGE ${ }^{1}$, in commenting on Mansour's note ${ }^{2}$ in Nature endeavoured to maintain two rather contradictory views, namely, (1) that the extracellular proteolytic and lipolytic enzymes recorded from the stomach juice of some lamellibranchs are derived from cytolized or burst phagocytes: (2) that extracellular proteolytic and lipoly tic enzvmes are absent from the stomach juice of lamellibranchs.

In maintaining that the extracellular proteolytic and lipolytic enzymes, recorded by different authors ${ }^{3,4,5}$, are derived from phagocytes, Prof. Yonge cites the work of Takatsuki ${ }^{6}$. The incompleteness of the experimental data of this author does not allow a comparison between his results and mine to be made. However, it is clear from his figures that the proteolytic and lipolytic actions of the concentrated extract of the amobocytes are much weaker than those reported from extract of the amobocytes are much weaker than those reported from
the stomach juice of the same sp. ${ }^{3}$. This point is against Yonge's the stomach juice of the same sp. ${ }^{3}$. This point is against Yonge's contention unless it can be definitely proved that phagocytes on than when ground up and extracted. 